\title{
Ürgék gyakoriságát befolyásoló élőhelyi tényezők vizsgálata
}

\author{
Szórádi Zsófia, Csete Sándor és Altbäcker Vilmos* \\ Szent István Egyetem, Kaposvári Campus, AKK Környezettudományi és \\ Természetvédelmi Intézet, 7400 Kaposvár, Guba Sándor u. 40. \\ E-mail:Altbacker.Vilmos@szie.hu
}

\begin{abstract}
Összefoglaló: A fokozottan védett közönséges ürgére (Spermophilus citellus) ható legkomolyabb veszélyeztető tényező az élőhelyeinek átalakulása és megszünése. Vizsgálatunkban 14 jelentős ürgepopuláció élőhelyét mértük fel a Dunántúlon és a Duna-Tisza közén az NBmR protokoll szerint, amit kiegészítettünk a talaj, a növényzet, valamint a tájhasználat vizsgálatával. Eredményeink alapján az ürgék változatos növényzetü, talajú és kezelésủ élöhelyeken fordulnak elö, de a legsürübb kolóniák a közepes kötöttségủ talajon kifejlődött, zárt, csenkesz fajok (Festuca spp.) által uralt gyepekben vannak. Közepes csenkesz-borítás mellett is létrejöhet nagy sűrüségü kolónia, ha azok erős legeltetésnek vagy rendszeres kaszálásnak vannak kitéve. A legsürübben lakott ürgeélőhelyek alacsonyabb növényi diverzitása felveti egy ürgére koncentráló élőhely-kezelés kidolgozásának szükségességét.
\end{abstract}

Kulcsszavak: Spermophilus citellus, ürgelyukszám, Festuca, cönológiai diverzitás, talajkötöttség

\section{Bevezetés}

A globális klímaváltozás és a tájhasználat átalakulása soha nem látott kipusztulási hullámot indított el az élővilágban (Millenium Ecosytem Assessment 2005). Ez a folyamat regionális léptékben hazánk élővilágát is érinti. Veszélyeztetett fajaink védelme nem vihető véghez az élőhelyeik védelme nélkül (Báldi et al. 2007). Ahhoz azonban, hogy a védelmi tevékenység célravezető legyen, meg kell ismernünk védett fajaink élőhelyi igényeit, különösen azokat, melyek a fajok számára kulcsfontosságúak.

A közönséges ürge (Spermophilus citellus Linnaeus, 1766) a Kárpát-medence területén is élő őshonos rágcsáló. A XX. század végéig gyakori mezőgazdasági kártevőnek számított, minden leadott ürgefarokért fizettek, illetve népi eledelként fogyasztották is (Lovassy 1927, Vásárhelyi 1964). Azonban az 1980-as évekre, feltehetően az állattartás visszaszorulásával, annyira lecsökkent élőhelyeinek és a lokális populációinak száma, hogy 1982-ben védetté (1/1982. (III. 15.) OKTH 
rendelkezés), majd 2001-ben fokozottan védetté nyilvánították (13/2001. (V. 9.) KöM rendelet), európai védettséget is élvez (Council 1992), az IUCN is a veszélyeztetett kategóriába sorolja (Hegyeli 2020). Az ürge, amíg nagy létszámban élt a pusztákon, a kerecsensólyom (Falco cherrug Gray, 1834) és a parlagi sas (Aquila heliaca Savigny, 1809) fó táplálékállata volt, de fokozott védettséget is a pusztai élővilágban betöltött kulcsfaj jellege miatt kapott (Benedek et al. 2007).

Az ürge járatának kiásása során talajhalmokat hoz létre a bejárati lyuk mellett, ezzel szabad talajfelszínt, új élőhelyet teremt, miközben ásásával befolyásolja a talajok fizikai, kémiai és biológiai tulajdonságait (Lindtner et al. 2019). Az általa ásott lyukakba behúzódhatnak a forróság elől a zöld varangyok (Bufo viridis Laurenti, 1768) és a fokozottan védett rákosi viperák (Vipera ursinii rakosiensis Méhely, 1893) is (Váczi et al. 1996). Az ürge szőrzete segítségével elősegítheti a növények magterjesztését, járatai pedig segítik a talaj szellőzését és vízgazdálkodását (Laundré 1998). Az ürge fontos élőlénye a gyepeknek, megóvása tehát elengedhetetlen a füves élőhelyek jól müködő egészséges természeti rendszerének fenntartásához. Ezt a kényes egyensúlyt alapjaiban veszélyezteti az élőhelyek átalakulása, melynek hátterében mind klimatikus, mind tájhasználat-változással kapcsolatos okok is állhatnak.

Az ürge nappali életmódja, viszonylagos ismertsége és kutatottsága alapján került a Nemzeti Biodiverzitás-monitorozó Rendszer (NBmR) által kiemelten követett fajok közé, így hazai állományainak változásáról részletes képünk van (Váczi et al. 2015). A lassan két évtizedes adatsor alapján mind az egyes állományok eltünése, mind a meglevő elszigetelt kolóniák kiesése gyakori, és a csökkenő trend megállítása és az azt kiváltó okok feltárása fontos feladat. Az ürgepopulációk létszámcsökkenése azért is érdemel fokozott figyelmet, mert míg a múltban az elterjedési terület perifériájáról szorult vissza az állomány, ma már a magpopulációk is pusztulnak (Cserkész 2018).

Az országos ürgeállomány további csökkenésének megelözése érdekében fontos megismernünk, hogy milyen élőhelyi adottságoktól függ az ürge jelenléte, hol alkotja a legsürübb kolóniákat. Vizsgálatunk ezen adottságok meghatározására irányult a Duna-Tisza köze és a Dunántúl jelentős ürgepopulációinak élőhelyein. Kutatásunk során arra kerestük a választ, hogy az egyes ürgeélőhelyek eltérő talajtani, vegetációs vagy tájhasználati különbségei mutatnak-e szoros kapcsolatot az ürgekolóniák sürüségével. Ha ezeket a jellemzőket megismerjük, akkor a jövőben hatékonyabbá válhatnak a védelmi intézkedések, célzott beavatkozással jobban elősegíthetjük az ürgeállományok stabilizálódását vagy akár növekedését is. 


\section{Anyag és módszer}

Az ürgeélőhelyek felmérésére 2018 májusa és júniusa során került sor. A vizsgálat keretében hazánk 14 jelentős ürgeélőhelyét mértük fel a Dunántúlon és a Duna-Tisza közén (1. ábra). A vizsgálatra kiválasztott ürgeélőhelyek a következők voltak: Siófok-Kiliti (repülőtér), Szentkirályszabadja (repülőtér), Tihany (Belső-tó déli partja), Öcs (juhlegelő), Kenyeri (volt repülőtér, ma juhlegelö), Dunakeszi (repülőtér), Kunpeszér (marhalegelö), Bugac (ló- és marhalegelő), Solt (juhlegelö), Németkér (Hardi-legelő), Paks (Ürge-mezö), Kápolnapuszta (Bivalyrezervátum), Budapest-Ferihegy (repülőtér) és Pécs-Pogány (repülőtér). Ezen állományok az eddigi NBmR adatok alapján elegendő létszámúak és stabilak voltak ahhoz, hogy a kolónián belüli sűrüség-ingadozásokat összevethessük az élőhelyen belüli talajés növényzeti tulajdonságokkal.

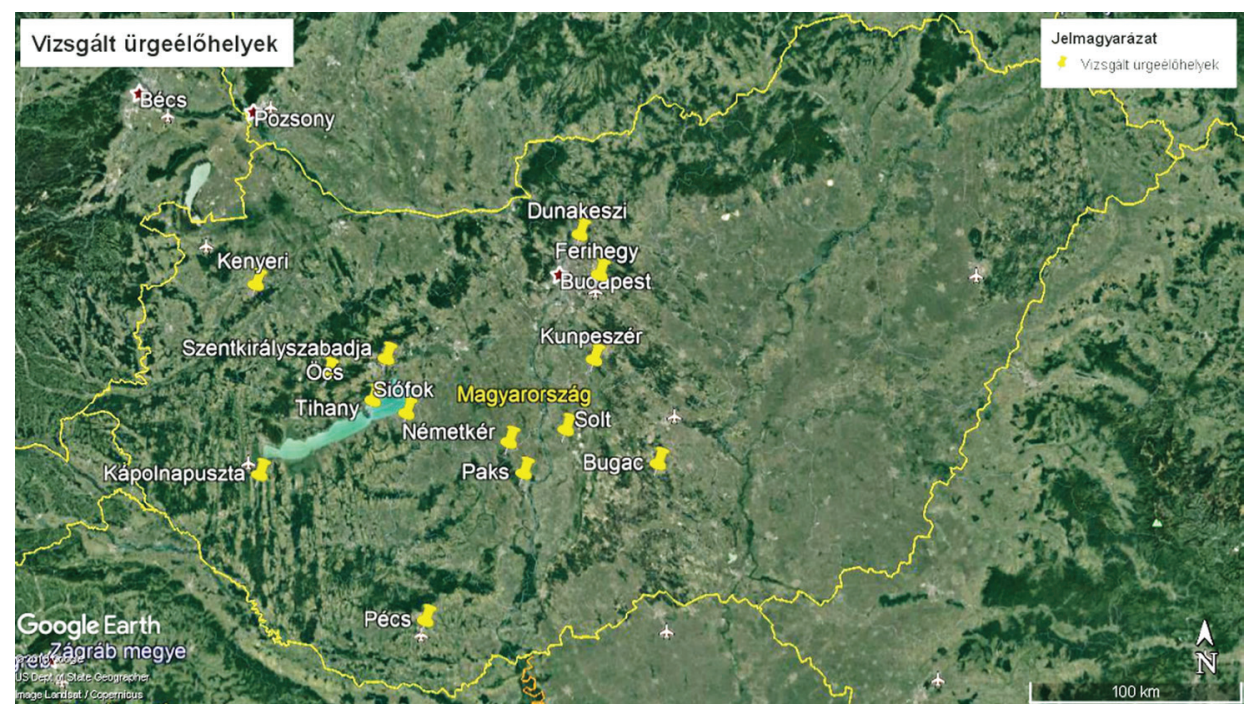

1. ábra: A vizsgált ürgekolóniák elhelyezkedése Magyarország területén.

Valamennyi élőhelyen vizsgáltuk az ürgepopuláció sürüségével párhuzamba állítható ürgelyuk-denzitást (Katona 1997), az adott élőhelyre jellemző fizikai talajféleséget, a növényzet összetételét, diverzitását és fiziognómiai jellemzőit (gyepmagasság, összborítás), valamint az élőhely kezelési módját.

Az ürgelyukak denzitásának felmérését a Nemzeti Biodiverzitás-monitorozó Rendszer módszertana szerint (Váczi et al. 2015) és annak helyszínein végeztük. Az ürgelyuk-számlálás 5 párhuzamos, egymástól 50 méterre lévő és egyenként 250 méter hosszú bejárási útvonalon történt (2. ábra). Az ürgelyukak száma a 250 

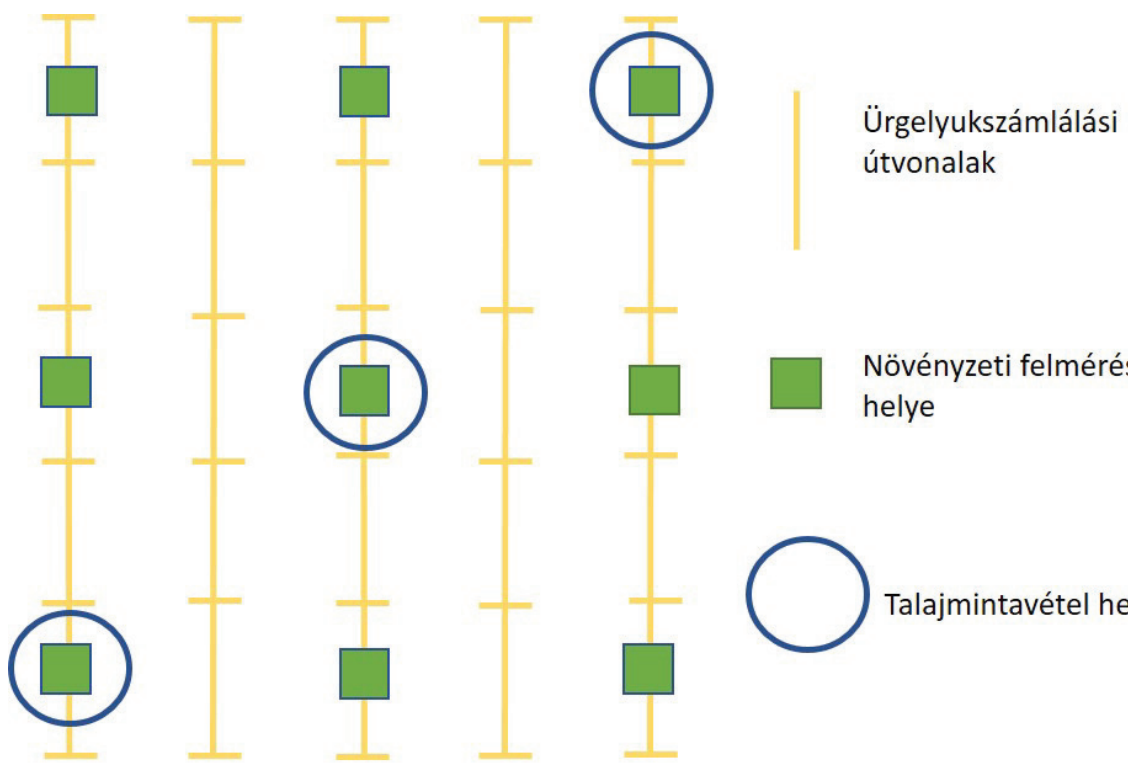

250 méter

2. ábra: A terepi mintavételek sematikus ábrája. A növényzeti (négyzet) és a talajminták (kör) felvétele szorosan kötődik az ürgelyukszámlálás útvonalaihoz, ami 5 db 250 méteres, 50 m-es szakaszokra bontott egységből áll.

méteres szakaszokon belül 5-5 darab 50 méter hosszú és 2 méter széles egységben lett megállapítva, így minden élőhelyen 25 , egyenletes eloszlású, egyenként 100 négyzetméteres mintaegységben került sor a lyukak denzitásának rögzítésére. Ebből a 25 adatból a cikk alapját képező elemzésekhez a növényzeti mintavételi helyekkel átfedő, élőhelyenként 9 adatot használtunk fel. Valamennyi e cikkben bemutatott elemzésben élőhelyenként ezen 9 adat átlagértékével számoltunk.

A növényzeti összborítás és a diverzitás összehasonlító elemzésekor az egyes élőhelyeket ürgelyuk-denzitás szempontjából három csoportba soroltuk. A csoportbeosztáshoz az adott élőhelyen mért ürgelyuk-sürüség medián értékét vettük figyelembe (1. táblázat). A csoportelnevezések (magas, közepes és alacsony) tükrözik az adott élőhelyre kapott mediánértékeket: magas (3-4 ürgelyuk/100 m²), közepes ( 2 ürgelyuk/100 $\mathrm{m}^{2}$ ), alacsony ( 1 ürgelyuk/100 $\mathrm{m}^{2}$ ), a korábbi vizsgálatokban tapasztaltaknak megfelelően (Váczi et al. 1996).

A növényzet mintavételezése helyszínenként $9 \mathrm{db} 1$ négyzetméteres kvadrátban történt az ürgelyuk-felmérés egységeihez szorosan igazodva, a 2. ábra szerinti elrendezésben. Minden egyes kvadráton belül 10 véletlenszerü ponton mértük a növényzet magasságát, meghatároztuk a gyökerező növényfajokat, a százalékos borítást fajonként, valamint a növényzet, a csupasz talajfelszín és az avar 
összborítását. A növényzeti magasságot és a növényzet összborítását mint fiziognómiai változókat használtuk az ürgeélőhelyek növényzetének összehasonlító elemzése során.

Élőhelyenként három darab, egyenként öt részmintából álló talajmintát gyüjtöttünk. Az egyes minták a 2. ábrán jelzett elosztásban az első, ötödik és kilencedik kvadrát körüli területrészről lettek begyüjtve, a talaj felső 12 centiméteres rétegéből. A fizikai talajféleség jellemzésére az Arany-féle kötöttségi számot használtuk $\left(\mathrm{K}_{\mathrm{A}}\right)$. Ennek kiszámításához először a begyüjtött talajmintákat légszáraz állapotban 2 milliméteres lyukátmérőjủ szitán átszitáltuk. Majd $50 \mathrm{~g}$ talajmintához anynyi desztillált vizet adtunk, hogy az elérje képlékenysége felső határát. A fogyott desztillált víz mennyiségét 100 g talajra vonatkoztatva kaptuk meg az Arany-féle kötöttségi számot.

A természetvédelmi kezelésre vonatkozó adatokat az élőhelyek kezelőitől kérdőíves módszerrel gyüjtöttük össze. A kérdőíveken a kezelt terület nagyságát (ha), az évenkénti kaszálások számát, a legeltetett állatok faját és létszámát, illetve a legeltetés időtartamát kérdeztük.

Az adatok elemzésekor többféle statisztikai eljárást használtunk. A növénycönológiai adatokat sokváltozós statisztikai módszerrel (fökomponensanalízis, PCA) elemeztük. Az egyes komponensek jelentéstartalmát a vizsgált fiziognómiai, növénycönológiai és talajtani változókkal való Spearman-korrelációjuk alapján értékeltük.

Az eltérö ürgelyuk-sürüségü (magas, közepes, alacsony) valamint az eltérően kezelt élőhelyek (juhlegelő, marhalegelő, nyírt gyep) tulajdonságai közötti különbségeket Kruskal-Wallis teszttel vizsgáltuk, post-hoc Dunn-tesztet alkalmazva az elsőfajú hiba csökkentésére. Szignifikancia-szintnek a p $<5 \%$ értéket választottuk.

Mivel a sokváltozós statisztikai vizsgálatok az egyes ürgeélöhelyek növényzeti különbségeiben kiemelt fontosságot tulajdonítottak a gyepalkotó csenkesz fajoknak, ezért a csenkesz (Festuca spp.) fajok hatását az ürgelyuksürüség alakulására külön is vizsgáltuk, lineáris regressziót alkalmazva. A talajok kötöttségi értékszáma és az ürgelyuksürüség értéke közötti összefüggést polinomiális regresszióval vizsgáltuk.

A diverzitás számításánál a Simpson-féle diverzitási indexet használtuk a következő formában: $1-\mathrm{D}$, ahol $\mathrm{D}=\Sigma \mathrm{pi}^{2}$, pi pedig az egyes növényfajok relatív borítása egy adott kvadráton belül. Valamennyi statisztikai vizsgálatot a Past 3.22 programmal végeztük (Hammer et al. 2001). 


\section{Eredmények}

A vizsgált ürgeállományok között és azokon belül is nagy eltéréseket találtunk az ürgelyukak sűrüségében (1. táblázat). A legsürübb ürgekolóniák esetében a 100 $\mathrm{m}^{2}$-re eső (50 méteren 2 méteres sávban talált) átlagos lyukszám három és négy közé adódott, míg a legritkább ürgeállományok esetén ez az érték éppen csak elérte az egyet.

1. táblázat: A vizsgált élőhelyeken mért átlagos, minimális és maximális ürgelyuk-sürüség.

\begin{tabular}{lccc}
\hline \multicolumn{1}{c}{ Élöhelyek } & Medián & Ürgelyuk-sürüség $\left(\mathrm{db} / 100 \mathrm{~m}^{2}\right)$ & \\
\hline & 4 & Min. & Max. \\
Dunakeszi & 4 & 1 & 7 \\
Öcs & 4 & 1 & 6 \\
Siófok-Kiliti & 4 & 1 & 5 \\
Pécs-Pogány & 3 & 1 & 6 \\
Szentkirályszabadja & 2 & 2 & 6 \\
Solt & 2 & 1 & 6 \\
Bugac & 2 & 1 & 5 \\
Budapest-Ferihegy & 2 & 0 & 5 \\
Tihany & 1 & 0 & 5 \\
Kunpeszér & 1 & 1 & 3 \\
Paks & 1 & 0 & 2 \\
Németkér & 1 & 0 & 2 \\
Kenyeri & 0 & 0 & 3 \\
Kápolnapuszta & & 0 & 5 \\
\hline
\end{tabular}

A növényzet összetétele alapján elvégzett főkomponens-analízis részben elkülönülő csoportokat rajzolt a vizsgált élőhelyek viszonylatában (3. ábra). Az uralkodó egyszikủek alapján jelentős volt az egyes felvételcsoportok szétválása. A PCA állapotteret meghatározó 1. komponens szoros korrelációt mutatott a csenkesz fajok (Festuca spp.) borításával (2. táblázat), az egyes felvételek közötti topológiai távolságok jelentős hányadáért (53\%) ez a változó volt a felelős. Az uralkodó egysziküek alapján négy növényzeti csoportba oszthatjuk a 14 mintavételi területünket. Az első csoportot a közönséges csillagpázsit (Cynodon dactylon (L.) Pers.) és az angolperje (Lolium perenne L.) által uralt, erősen legeltetett, üdébb, réti jellegủ gyepek alkotják (jellemzően Tihany, Solt és Kápolnapuszta). A következő csoportra a barázdált és a sovány csenkesz (Festuca rupicola Heuff. és $F$. pseudovina Hack.) dominanciája jellemző (Öcs, Kenyeri, Kunpeszér, Dunakeszi, 


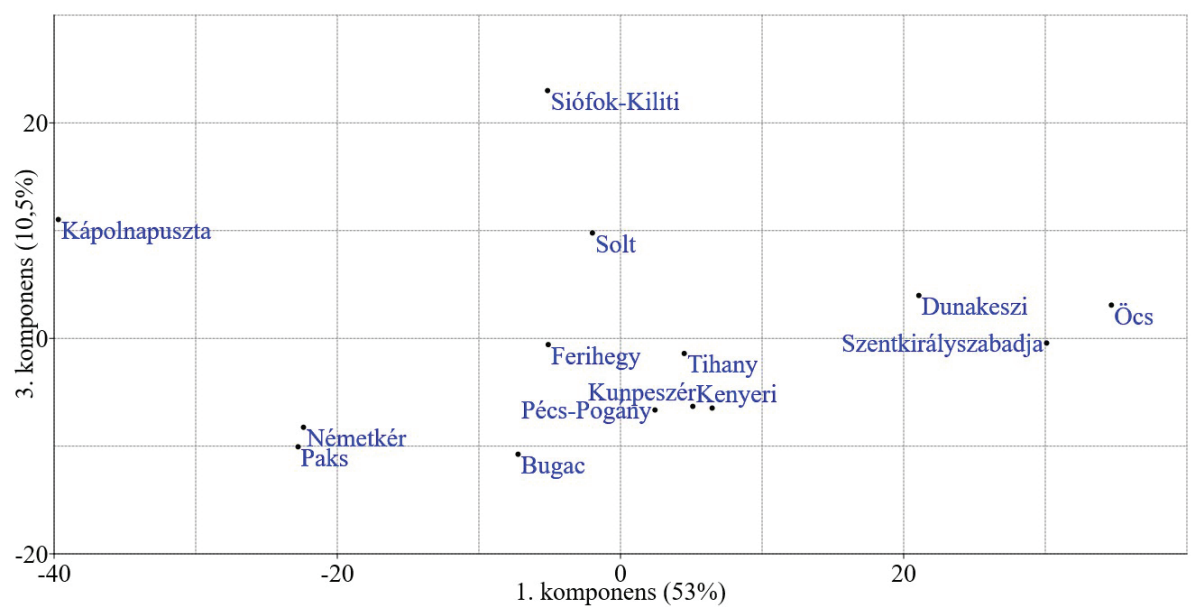

3. ábra: A vizsgált ürgeélőhelyek cönológiai mintáinak főkomponens-analízise. Az 1. komponens a Festuca-borítással, míg a 3. komponens a növényzet összborításával korrelál szorosan. (A tengelyeken zárójelben az adott komponensre jutó varianciahányad látható.)

Bugac, Szentkirályszabadja). Külön csoportot alkotnak a sás fajok (Carex spp.) uralta száraz, nyílt homoki gyepek (Németkér, Paks). A negyedik csoportba jellemzően az árva rozsnok (Bromus inermis Leyss.) tömegességével jellemezhető gyepek kerültek, melyek rendszeresen kaszált reptereken fordultak elő (SiófokKiliti, Budapest-Ferihegy).

Erös korrelációt találtunk a PCA 3. komponense és a növényzeti összborítás között is (2. táblázat). A 3. komponens az összvariancia 10,5\%-át képviselte. A tengely mentén elváló élőhelyek növényzete jelentősen eltért egymástól a talajfelszín borítottságát tekintve, bár e fiziognómiai jellemző tekintetében közel sem volt akkora változatosság a vizsgált élőhelyek között, mint a gyepek fajöszszetételében. Az összborítás mértéke a paksi homokterületen volt a legkisebb (45\%), míg a föleg kötött, üde termőhelyeken ez az érték több élőhelyen is (pl. Solt, Szentkirályszabadja, Tihany) meghaladta a 90\%-ot. Az összborítás mértékére a vizsgált gyepek mindegyikében az egysziküek voltak legnagyobb hatással, így e két változó között is szoros korrelációt kaptunk valamennyi vizsgált élőhely esetében (2. táblázat).

Az ürgekolóniák nagyobb lyuksürüségü állományrészei szignifikánsan kapcsolódtak a talajok mechanikai ellenállásának nagyságára jellemző ún. Arany-féle kötöttségi szám nagyobb értékeihez ( $\mathrm{rs}=0,57)$. Szignifikáns összefüggést kaptunk az ürgelyukak sürüsége és az egyszikủek borítása között is ( $\mathrm{rs}=0,69)$. Mivel az egysziküborításért sokszor a Festuca fajok voltak a felelősek, így nem meglepö, hogy a nagyobb ürgelyuksürúséget mutató területrészekhez a Festuca nemzetség 
2. táblázat: Az ürgelyuk-sűrűség és a vizsgált élőhelyi változók közötti kapcsolatok. Az átló alatti értékek a Spearman-korrelációs együtthatók (rs), míg az átló fölött tükrözve az összefüggéshez tartozó valószínüségi érték (p) található. *: $\mathrm{p}<5 \%$; **: $\mathrm{p}<1 \%$; ***: $\mathrm{p}<0,1 \%$

\begin{tabular}{|c|c|c|c|c|c|c|c|c|c|c|}
\hline $\mathrm{rs} / \mathrm{p}$ & 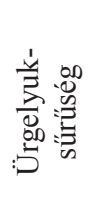 & 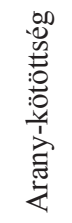 & 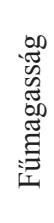 & 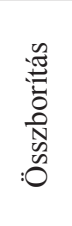 & 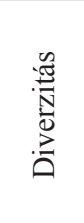 & 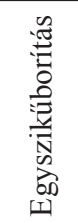 & 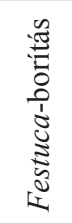 & $\vec{Q}$ & $\underset{U}{U}$ & $\bigcup_{0}^{n}$ \\
\hline Ürgelyuk-sürüség & & $*$ & & & & $* *$ & $*$ & & & \\
\hline Arany-kötöttség & 0,57 & & & $* * *$ & & $* * *$ & & & & $*$ \\
\hline \multicolumn{11}{|l|}{ Fümagasság } \\
\hline Összborítás & & 0,79 & & & & $* * *$ & & & $*$ & $* *$ \\
\hline Diverzitás & & & & & & & $*$ & $*$ & & \\
\hline Egysziküborítás & 0,69 & 0,79 & & 0,86 & & & $* *$ & $*$ & $*$ & $* *$ \\
\hline Festuca-borítás & 0,56 & & & & $-0,61$ & 0,69 & & $* * *$ & & \\
\hline PC 1 & & & & & $-0,62$ & 0,65 & 0,99 & & & \\
\hline PC 2 & & & & 0,65 & & 0,62 & & & & \\
\hline PC 3 & & 0,57 & & 0,69 & & 0,77 & & & & \\
\hline
\end{tabular}

is nagyobb borítással kapcsolódott (rs=0,56) (2. táblázat és 4. ábra). Az összefüggés szorossága a Festuca-borítás értékeitől függött. Alacsony és magas borításnál szoros illeszkedést, míg közepes Festuca-borításnál jelentős variabilitást és laza illeszkedést találtunk az ürgelyukak sürüségében. Az ürgeélőhelyek vegetációjának diverzitása ugyanakkor nem mutatott korrelációt az ürgék intenzívebb jelenlétét mutató ürgelyuk-denzitással.

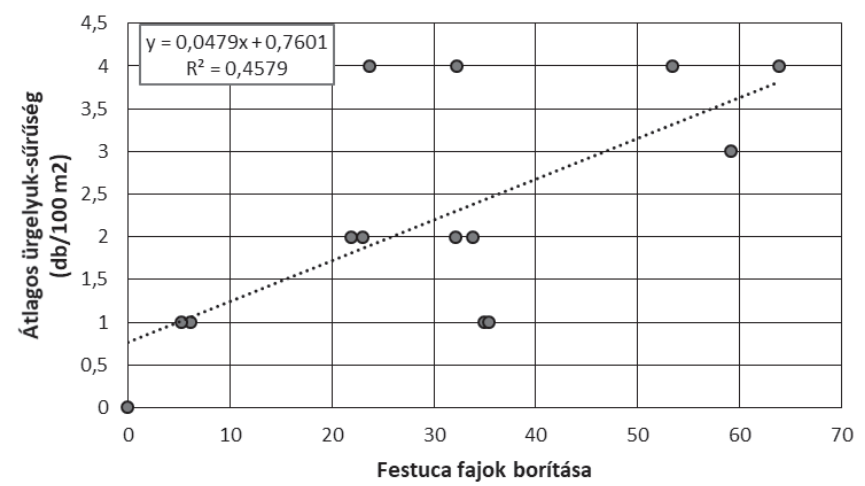

4. ábra: Az élőhelyenként átlagolt ürgelyuk-sűrüség $\left(\mathrm{db} / 100 \mathrm{~m}^{2}\right)$ és a Festuca fajok százalékos borítása közötti kapcsolat. A pontozott vonal a lineáris regresszió értékét mutatja. 
Az egyes ürgeélőhelyek kezelési módja és az ürgék lyuksürüsége közötti kapcsolatot támasztja alá az 5. ábrán látható szignifikáns összefüggés $(H=10,5$; $\mathrm{p}<0,01)$. Azokon a területeken, ahol jellemző a juhokkal történő legeltetés, illetve a kaszálás, jelentősen nagyobb lyukszámokat találtunk egységnyi területen $(2,6$

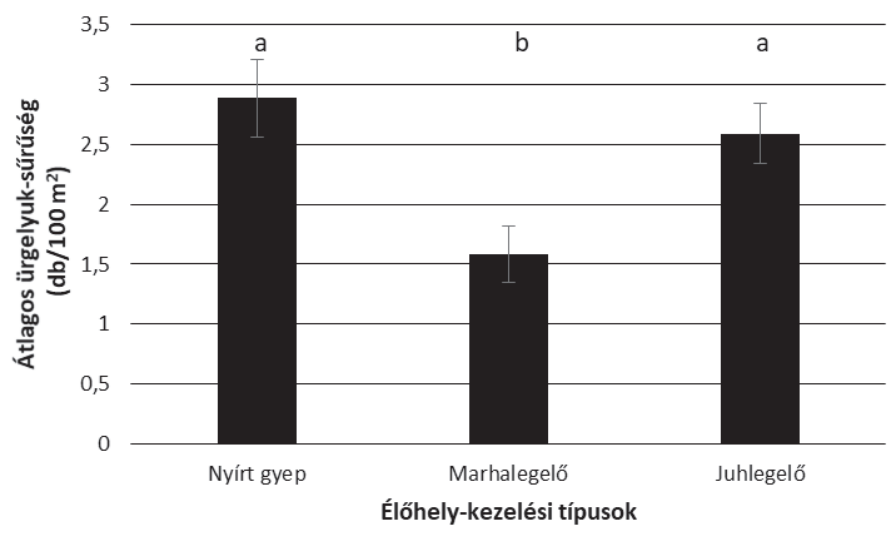

5. ábra: Az élőhelyenként átlagolt ürgelyuk-sűrüség (átlag+SE) az eltérő kezelésű élőhelyeken. Az oszlopok feletti eltérő betűk a szignifikánsan különböző csoportokat jelölik.

illetve 2,9 ürgelyuk $\left./ 100 \mathrm{~m}^{2}\right)$, mint a szarvasmarhával legeltetett területek átlagosnál alacsonyabb ürgelyuk-denzitásai $\left(1,6\right.$ ürgelyuk $\left./ 100 \mathrm{~m}^{2}\right)$. A 4. ábrán látható magas Festuca-borítású élőhelyek valamennyien kiemelkedő ürgelyuk-sürüségü élőhelyek voltak: Öcs, Szentkirályszabadja és Dunakeszi. Közös jellemzőjük a birkával való rendszeres legeltetés is. A közepes Festuca-borítású gyepek közül az átlagnál nagyobb lyuksürüségủ területek rendszeresen kaszáltak voltak (SiófokKiliti, Pécs-Pogány). Ezzel szemben azokat a közepes Festuca-borítású gyepeket, melyek az átlagnál alacsonyabb ürgelyuk-sürüségüek voltak marhalegelőként hasznosították (Kunpeszér), vagy ugyan birkalegelők voltak, de csak időszakosan legeltették őket (Kenyeri).

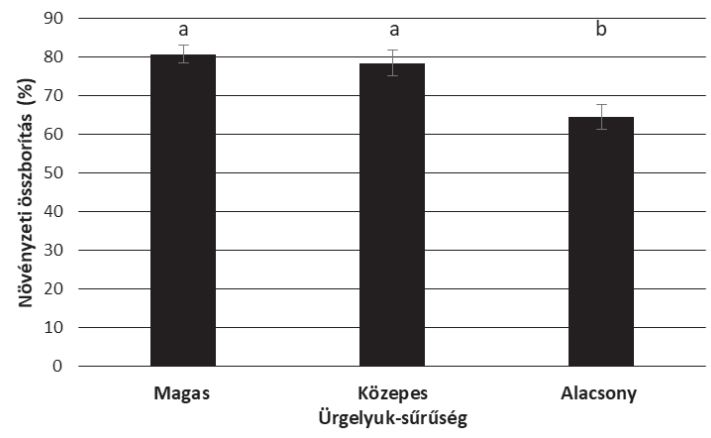

6. ábra: A növényzeti összborítás (átlag+SE) értékei az eltérö ürgelyuk-sürüségü élőhelyeken. $\mathrm{Az}$ oszlopok feletti eltérö betük a szignifikánsan különböző csoportokat jelölik. 
Az ürgeélőhelyek növényzetének fiziognómiai jellemzői közül az összborítás alakulását mutatja a 6. ábra. Az ábra alapján látható, hogy a magas és közepes ürgelyuk-sürüségủ élőhelyeken a vegetáció egyformán zárt ( $80 \%$ körüli borítási értékkel bír), míg az alacsony ürgelyuk-sürüségú élőhelyeket felnyíló növényzet jellemzi, ahol az összborítás átlagban nem haladja meg a 60\%-ot $(\mathrm{H}=17,05$; $\mathrm{p}<0,001)$.

A növényi diverzitást vizsgálva (7. ábra) látható, hogy a nagy ürgelyuk-sürüségủ élőhelyek diverzitása alacsonyabb a közepes és alacsony ürgelyuk-sürüségủ élőhelyekénél $(H=24,93 ; p<0,001)$. A különbség mértéke ugyanakkor nem túl nagy ( 0,1 körüli).

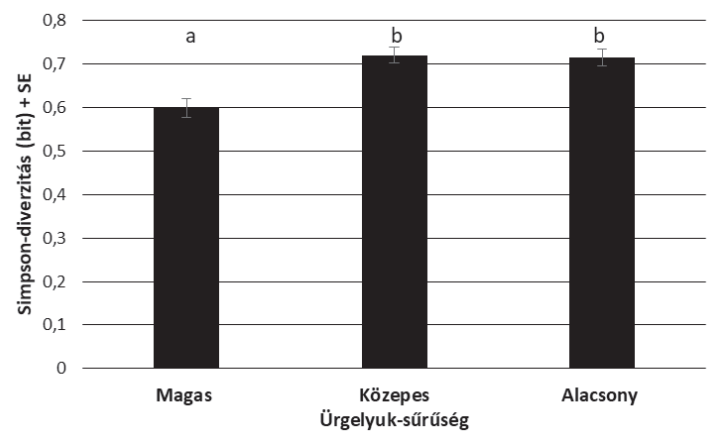

7. ábra: A cönológiai diverzitás (Simpson-diverzitás, átlag + SE) alakulása az eltérö ürgelyuksürüségü élőhelyeken. Az oszlopok feletti eltérő betük a szignifikánsan különböző csoportokat jelölik.

A 8. ábrán mutatjuk be az Arany-féle kötöttségi szám és a lyuksürüség részletesebb, regresszióvizsgálattal kapott összefüggését. Minél kisebb az Arany-féle kötöttségi szám, annál lazább a talaj, vagyis annál kevésbé áll ellen bármiféle mechanikai hatásnak. Első megközelítésben láthatjuk, hogy kötöttebb talajú élőhe-

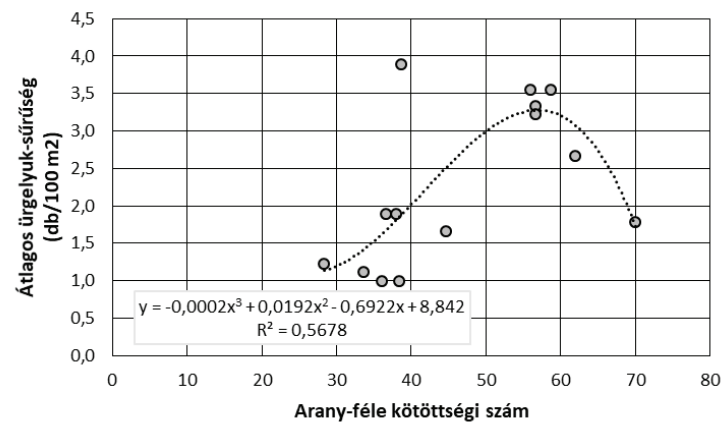

8. ábra: Az élőhelyenként átlagolt ürgelyuk-sürüség $\left(\mathrm{db} / 100 \mathrm{~m}^{2}\right)$ és az Arany-féle kötöttségi szám közötti kapcsolat. A pontozott vonal a polinomiális regressziós összefüggést mutatja, feltüntettük a regressziós függvényt is. 
lyeken lényegesen nagyobb az ürgekolóniák átlagos lyuksürüsége a lazább talajú élőhelyekhez képest. Míg a laza, homokos vályogtalajoknál az átlagos lyuksürüség értéke 1 körülinek adódott 100 négyzetméterenként, addig az agyagtalajoknál ez az érték 3-3,5 volt. Az Arany-féle kötöttségi szám további növekedésével $\left(\mathrm{K}_{\mathrm{A}}>60\right)$ ugyanakkor az ürgelyuk-sürüség értéke újra csökkenni kezdett, majd 2 alá esett.

\section{Diszkusszió}

Vizsgálataink alapján megállapítottuk, hogy az ürgék többféle domináns növényzetü élöhelyen élnek. Ezek különbözhetnek kezelésükben és keletkezésükben is: lehetnek felülvetett gyepek, évszázadok óta hasznosított juh- vagy marhalegelők, esetleg kaszált vagy juhok által legeltetett repülőterek. Hasonlóan széles spektrumú élőhelyi adottságokat találtak Matějů et al. (2011) Csehországban, és Zaharia et al. (2016) Romániában.

Különböző élőhelyi tényezők hatását vizsgálva szoros kapcsolatot találtunk az ürgelyuk-sürüség és a növényzeti diverzitás, az egyszikü-borítás és az Arany-féle kötöttségi szám között, a legszorosabb összefüggést pedig a lyuksürüség és a Festuca-borítás mutatta. Ezek alapján feltételezhető, hogy a Festuca fajok jelenléte kiemelkedően fontos az ürgék számára. Ezt támasztja alá Altbäcker (2007) valamint Gedeon és munkatársainak (2010) vizsgálata is, melyek során a felkínált Festuca és Bothriochloa fajok közül kizárólag a Festucát választották az állatok fészkeik építésére. A táplálkozásukban is nagy szerepet játszanak ezek a fajok, 10-30\%-át is alkothatják az elfogyasztott növényeknek (Győri-Koósz et al. 2013).

A vizsgált élőhely-kezelési adatok alapján megállapítottuk, hogy még alacsonyabb Festuca-borítású élőhelyek is átlag feletti ürgepopulációt tarthatnak fenn, ha azokat rendszeresen legeltetik birkával, vagy gyakran nyírják/szárzúzzák őket (vö. Váczi \& Altbäcker 1999). Ha azonban a hasonló növényzetủ gyepekben az élőhelyek kezelését felhagyják, vagy a legeltetést marhával végzik, az ürgeállományok sürüsége lecsökkenhet. A marhával történő legeltetés, ha nem elég intenzív, ugyan változatos kétszikü fajkészletet tart fenn, de az ürgék számára fontos rövidfüves gyep fenntartásához nem elegendő. A marhalegelőn élő ürgék valószínüleg kedvezőbb táplálékkínálatból válogathatnak, de a birkalegelő ürgéi a megfelelőbb struktúrájú élőhely miatt nagyobb egyedszámot érhetnek el (Gedeon et al. 2011).

Az általunk vizsgált élőhelyek közül a legkedvezőbbek az ürgék számára a rendszeresen kaszált vagy az intenzív birkalegelésnek kitett területek voltak. Tapasztalatunk szerint rendszeres kaszálás leginkább repülőterek vagy nemzeti parki bemutatóhelyek környékén fordult elö, ahol az ürgéknek is kedvező állapotú 
gyepek létrejöttét vagy fennmaradását valamilyen, a természetvédelmi célokon túlmutató emberi tevékenység alapozta meg. A juhlegeléssel hasznosított gyepek sem egyöntetüen lehetnek alkalmasak nagy sürüségü ürgepopulációk fenntartására annak ellenére sem, hogy a legelők gyepmagasságát elviekben egységesen alacsonyan lehet tartani ezzel a kezelési móddal (Ónodi et al. 2008). A terepi megfigyeléseink szerint egy-egy juhlegelő rendszerint a hodályok környékén a legintenzívebben legelt, és az ürgekolóniák nagyobb lyuksürüségü része is rendszerint ide koncentrálódott.

A felnyíló gyepekben kisebb az ürgék egyedszáma. Az általuk preferált gyepek általában zártak, továbbá ezekben viszonylag fajszegény a növényzet, és az egyszikü-borítás magas, ami a gyakori kaszálás és az intenzív legeltetés hatására alakulhatott ki. A növényi diverzitás tekintetében nem találtunk különbséget az eltérö ürgelyuk-sürüségü élőhelyek között az alacsony és a közepesen magas lyuksűrüségü ürgekolóniák területén, de szignifikánsan alacsonyabbnak bizonyult a diverzitás a magas ürgelyuk-sürüségü területen. A különbség mértéke ugyanakkor nem túl nagy. Mivel a használt diverzitási index (Simpson-index) kifejezetten nem érzékeny a ritka fajokra (Tóthmérész 1997), feltételezhetjük, hogy a fenti csekély diverzitásbeli különbség nagyrészt a közepesen gyakori vagy gyakori fajok alacsonyabb számának, esetleg azok egyenetlen abundanciájának köszönhető. A magas ürge-sürüségü helyeken tapasztalt alacsonyabb növényzeti diverzitási érték utalhat arra, hogy az ürge számára kedvező rövidfüves legelőt eredményező legeltetési nyomás valamivel erősebb kell, hogy legyen, mint ami a növényzeti diverzitás szempontjából optimális lenne (vö. Csecserits et al. 2001). Ugyanakkor a kapott eredményeink összecsengenek Győri-Koósz és munkatársai (2013) vizsgálatával is. Ebben megállapították, hogy az ürgék táplálkozásában jelentős részarányt képviselnek a kétszikủek, így azok számának csökkenése érzékenyen érintheti az ürgeélőhelyek növényi diverzitását is.

Korábban többen is beszámoltak arról, hogy a gyepmagasság befolyásolta az ürgék élőhely-választását. Kis és munkatársai (1998) kísérletükben bizonyították, hogy gyepek magasságának változása még rövid távon is hatással lehet az ürgék élőhelyen belüli területfoglalására, így sűrüségére is. Esetükben a rövid és hosszú füvü gyep magasságkülönbsége kb. 50 cm volt. Kenyeres és munkatársai (2018) szintén fontos változóként definiálták az ürgeélőhelyek fümagasságát. Vizsgálatukban kimutatták, hogy már kisebb magasságbeli különbség is $(\sim 10 \mathrm{~cm})$ elegendő lehet magasabb ürgesürüség létrejöttéhez. Ugyanakkor cikkükben nem tesznek említést arról, hogy mikor, hányszor és milyen módon mérték a gyep magasságát, így nem tudhatjuk, hogy az általuk bemutatott értékek az ürgék aktív időszakára jellemző átlagértékek-e, vagy csupán az év valamilyen kitüntetett rövidebb időszakára vonatkoznak. 
Vizsgálatunkban a növényzet magassága nem mutatott szignifikáns korrelációt az ürgék lyuksürüségével. Az általunk vizsgált gyepmagassági értékek élőhelyenként egyszeri, május-június folyamán elvégzett mérésből származnak. Nem tudjuk ugyanakkor, hogy ez a magasságmérési időszak hogyan viszonyul a legeltetés vagy a gyepek nyírásának időzítéséhez, mely ismeret elengedhetetlen lenne annak megbecsüléséhez, hogy a mért magassági értékek miképpen viszonyulnak az ürgeélőhelyek egész éves jellemző gyepmagasságához.

Mivel a növényzet struktúrája és összetétele nemcsak a kezelési módtól, hanem az abiotikus tényezőktől, így a talajtípustól is függ, ezért vizsgáltuk az ürgék élöhely-választása és a növényzet szempontjából lényegesnek tủnő talajtulajdonságokat is. Az ürgék élöhelyfoglalása a járatok elkészítése nélkül nem mehet végbe. A talajok mechanikai ellenállóképessége a kotorékok kiásásának idejét, a kotorék készítésére fordított energia nagyságát döntően meghatározhatja. Vizsgálatunkból kiderült, hogy a közepesen kötött talajokon a lyuksürüség sokszorosa lehet a laza talajok lyuksürüségének, ugyanakkor a nehéz agyagtalajok $\left(\mathrm{K}_{\mathrm{A}}>60\right)$ az egységnyi területen vett ürgelyukszám csökkenését hozták magukkal. Ennek hátterében különböző okok állhatnak. Valószínü, hogy a Katona és munkatársai (2002) által korábban Bugacpusztán végzett részletes vizsgálatnak megfelelően a lazább, homoktalajokon létrehozott ürgelyukak tartóssága kisebb, a legelő állatok taposása hatására vagy a járművek nyomvonalai mentén beomolva csökken a felmérhető lyukszám, még akkor is, ha a kolónia mérete lényegében nem változik. Ugyanakkor az agyag- és vályogtalajok a kiásott lyukakat tovább is megőrzik, mint a lazább homokos vályog, illetve homoktalajok. Ezzel szemben már korábbi vizsgálatok is utalnak arra (Altbäcker, nem publikált adat), hogy erősen kötött talajoknál vagy sziklás-köves termőhelyeken az ürgék karomkopása kifejezetten nagyobb mértékủ az ásás következtében. Így mi is joggal feltételezhetjük, hogy az igen kötött ún. nehéz agyagtalajú élőhelyeken lecsökkenő átlagos ürgelyukszám nem a véletlen müve, hanem a sokkal nehezebb ásási lehetöségek tükröződnek benne. Hasonló következtetésre jutottak Janderková és munkatársai (2011) illetve Kenyeres és munkatársai (2018), akik kimutatták, hogy az ürgék nem preferálják a nehezebben ásható, köves és magas agyagtartalmú talajokat. Hasonló fizikai korlátokat állapítottak meg prérikutyák élőhelyválasztásában is (Wagner \& Drickamer 2004).

Az általunk vizsgált, viszonylag nagy és stabil ürgeállományokon túl jelentős mennyiségü csökkenő létszámú kolónia is található hazánkban (Cserkész 2018). Vizsgálataink alapján javasoljuk erős legeltetés vagy gyakori szárzúzás/kaszálás alkalmazását minden ilyen élőhelyen, mely reményeink szerint hozzájárulhat az ürgepopulációk stabilizálásához vagy növeléséhez az élőhelyül szolgáló gyepek közepes diverzitásának fenntartása mellett. A javasolt élőhelykezelési módszertan pontos részleteinek kidolgozása (pl. a kaszálás/szárzúzózás évenkénti ismétlés- 
számának, a legelési nyomásnak vagy a kezelések időzítésének meghatározása) még további vizsgálatokat igényel, de a már itt bemutatott eredményeink is segíthetik a hazai természetvédelmi gyakorlatot a fokozottan védett ürge állománycsökkenésének megállításában.

Köszönetnyilvánitás - A munka a LIFE13NAT/HU/00018 számú LIFE+NATURE pályázat, valamint az EFOP-3.6.3-VEKOP-16-2017-00005, illetve az EFOP-3.6.3VEKOP-16-2017-00008 keretében kiírt TDK-kutatás pályázat támogatásával zajlott. Köszönjük dr. Vadász Csabának és a Balaton-felvidéki Nemzeti Park Igazgatóság munkatársainak a terepi munkában nyújtott segítségüket, a védett területek kezelőinek a készséges információszolgáltatást, és köszönjük a cikk bírálóinak értékes javaslatait, mellyel jelentősen hozzájárultak a cikk jobbá tételéhez.

\section{Irodalomjegyzék}

Altbäcker, V. (2007): Szaporodási stratégiák vizsgálata az ürgénél (Spermophilus citellus). - OTKA Zárójelentés. ELTE Etológia Tanszék, Göd, 23 p.

Báldi, A., Batáry, P., Erdős, S., Kisbenedek, T., Orci, K. M., Orosz, A., Podlussány, A., Rédei, D., Rédei, T., Rozner, I., Sárospataki, M., Szél, Gy. \& Szüts, T. (2007): Legelés intenzitásának hatása alföldi gyepek biodiverzitására. - Termvéd Közlem. 13: 249-257.

Benedek, Zs., Jordán, F. \& Báldi, A. (2007): Kulcsfajkomplexek kutatása és ennek alkalmazási perspektívái a természetvédelem hatékonyságának növelésében. - Termvéd Közlem. 13: 27-36.

Council (1992): Council Directive 92/43/EEC on the conservation of natural habitats and of wild fauna and flora. Official Journal of the European Communities No. L 206: 7-50. Consolidated version 01/01/2007.

Csecserits, A., Váczi, O., Katona, K. \& Altbäcker, V. (2001): Optimális legelési intenzitás vizsgálata homokpusztagyepben. - In: Nagy, G. (szerk.) Gyepgazdálkodásunk helyzete és kilátásai: Többirányú gyephasználat szaktanácsadási alapjai. III. Debreceni Gyepgazdálkodási Napok, Debrecen, pp. 34-38.

Cserkész, T. (2018): Az ürge (Spermophilus citellus) gyakoriságának változása Magyarországon 1950 és 2017 között. - LIFE13NAT/HU/000183 számú „A kerecsensólyom és a parlagi sas táplálékbázisának megőrzése a Kárpát-medencében” LIFE+NATURE projekt A1 akció. 25 p.

Gedeon, Cs., Markó, G., Németh, I., Nyitrai, V. \& Altbäcker, V. (2010): Nest material selection affects nest insulation quality for the European ground squirrel (Spermophilus citellus). - J. Mammal. 91: 636-641. https://doi.org/10.1644/09-MAMM-A-089.1

Gedeon, Cs., Boross, G., Németh, A. \& Altbäcker V. (2011): Release site manipulation to favour European ground squirrel Spermophilus citellus translocations: translocation and habitat manipulation. - Wildl. Biol. 17: 97-104. https://doi.org/10.2981/10-124

Győri-Koósz, B., Katona, K. \& Altbäcker, V. (2013): Az ürge (Spermophilus citellus) étrendjének vizsgálata legelt és kaszált gyepterületeken. - Magyar Apróvad Közl. 11: 215-226.

Hammer, O., Harper, D. A. T. \& Ryan, P. D. (2001): PAST: Paleontological Statistics software package for education and data analysis. - Palaeontol Electron 4: 1-9.

Hegyeli, Z. (2020): Spermophilus citellus. - The IUCN Red List of Threatened Species 2020: e.T20472A91282380 https://doi.org/10.2305/IUCN.UK.2020-2.RLTS.T20472A91282380.en. 
Janderková, J., Matějů, J., Schnitzerová, P., Petruš, J., Sedláček, J. \& Uhlíková, J. (2011): Soil characteristics at Spermophilus citellus localities in the Czech Republic (Rodentia, Sciuridae). - Lynx n. s. (Praha) 42: 99-111.

Katona, K. (1997): Az ürge (Spermophilus citellus) mikrohabitat használata Bugacpusztán. - Szakdolgozat, ELTE, Etológia Tanszék, Göd, 47 p.

Katona, K., Váczi, O. \& Altbäcker, V. (2002): Topographic distribution and daily activity of the European ground squirrel population in Bugacpuszta, Hungary. - Acta Theriol 47: 45-54. https:// doi.org/10.1007/BF03193565

Kenyeres, Z., Bauer, N., Nagy, L. \& Szabó, Sz. (2018): Enhancement of a declining European ground squirrel (Spermophilus citellus) population with habitat restoration. - J. Nat. Conserv. 45: 98-106. https://doi.org/10.1016/j.jnc.2018.08.006

Kis, J., Váczi, O., Katona, K. \& Altbäcker, V. (1998): A növényzet magasságának hatása a cinegési ürgék élőhelyválasztására. - Termvéd Közlem. 7: 117-123.

Laundré, J. W. (1998): Effect of ground squirrel burrows on plant productivity in a cool desert environment. - J. Range Manage. 51: 638-643.

Lindtner, P., Gömöryová, E., Gömöry, D., Stašiov, S. \& Kubovčík, V. (2019): Development of physico-chemical and biological soil properties on the European ground squirrel mounds. - Geoderma, 339: 85-93. https://doi.org/10.1016/j.geoderma.2018.12.043

Lovassy, S. (1927): Magyarország gerinces állatai és gazdasági vonatkozásaik. - Királyi Magyar Természettudományi Társulat, Budapest, 895 p.

Matějů, J., Šašek, J., Vojta, J. \& Poláková, S. (2011): Vegetation of Spermophilus citellus localities in the Czech Republic (Rodentia : Sciuridae). Vegetace na lokalitách sysla obecného (Spermophilus citellus) v České republice (Rodentia : Sciuridae). - Lynx, n. s. (Praha) 42: 133-143.

Millennium Ecosystem Assessment (2005): Ecosystems and human well-being: Synthesis. - Island Press World Resources Institute, Washington, DC. https://doi.org/10.1007/978-94-007-6172$\underline{881-1}$

Ónodi, G., Csatádi, K., Németh, I., Váczi, O., Botta-Dukát, Z., Kertész, M. \& Altbäcker, V. (2008): Birka- (Ovis aries L.) és nyúllegelés (Oryctolagus cuniculus L.) hatásainak vizsgálata az égésre homokpusztagyepekben. - Termvéd Közlem. 14: 117-129.

Tóthmérész, B. (1997): Diverzitási rendezések. - Scientia Kiadó, Budapest, 98 p.

Váczi, O. \& Altbäcker, V. (1999): Füves repülőterek ürgeállományának felmérése. - Termvéd Közlem. 8: 205-214.

Váczi, O., Katona, K. \& Altbäcker, V. (1996): A bugacpusztai ürgepopuláció tér- és időbeli mintázata. - Vadbiológia 5: 141-148.

Váczi, O., Altbäcker, V. \& Takács, G. (2015): Ürgemonitorozás. - Természetvédelmi Információs Rendszer, Központi protokoll: 9.

Wagner, D. \& Drickamer. L. C. (2004): Abiotic habitat correlates of Gunnison's prairie dog in Arizona. - J. Wildl. Manage. 68: 188-197. https://doi.org/10.2193/0022-541X(2004)068[0188: AHCOGP $] 2.0 . \mathrm{CO} ; 2$

Vásárhelyi, I. (1964): Borsod-Abaúj-Zemplén megye gerinces faunája. - Kézirat.

Zaharia, G., Petrencu, L. \& Baktag, E. S. (2016): Site selection of European ground squirrels (Spermophilus citellus) in Eastern Romania and how they are influenced by climate, relief, and vegetation. - Turk. J. Zool. 40: 917-924. http:// doi:10.3906/zoo-1505-28 
Hivatkozott jogszabályok:

1/1982. (III. 15.) OKTH rendelkezés a védett és fokozottan védett növény- és állatfajokról, egyedeik értékéröl, a fokozottan védett barlangok körének megállapításáról, valamint egyes védett állatfajokkal kapcsolatos korlátozások és tilalmak alóli felmentésekről

13/2001. (V. 9.) KöM rendelet a védett és a fokozottan védett növény- és állatfajokról, a fokozottan védett barlangok köréröl, valamint az Európai Közösségben természetvédelmi szempontból jelentős növény- és állatfajok közzétételéröl

\title{
Habitat characteristics affecting the density of European ground squirrel colonies
}

\author{
Zsófia Szórádi, Sándor Csete \& Vilmos Altbäcker*
}

\section{Szent István University, Kaposvár Campus, Institute of Environmental Sciences and Nature Conservation, H-7400 Kaposvár, Guba Sándor u. 40., Hungary \\ E-mail:Altbacker.Vilmos@szie.hu}

Habitat loss and degradation are major concerns in the recent reduction of biodiversity. Habitat characteristics around the largest remaining European ground squirrel colonies were evaluated in the western part of Hungary. We supposed that both within and between colonies, ground squirrel densities indicate habitat quality. We found that ground squirrels inhabit grasslands with various soil types of medium hardness, but they reached the highest density in fescue (Festuca spp.) dominated, from moderately to heavily grazed or frequently mowed grasslands. As this strictly protected animal is a key species in the steppe ecosystem, we suggest following specific management measurements, targeting the habitat characteristics preferred by this species, in order to protect the remaining colonies.

Keywords: Spermophilus citellus, hole density, Festuca spp., plant diversity, soil hardness 